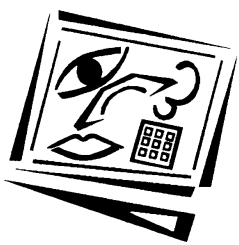

Australasian Journal of Educational Technology

Volume 28, Number 1, 2012

ISSN 1449-5554 (online)

\title{
Contents
}

Editorial 28(1): Outstanding Paper Awards, ascilite Hobart 2011

iii-iv

\section{Outstanding Paper Awards}

Academic analytics in a medical curriculum: Enabling educational excellence Martin Olmos and Linda Corrin

Leading change: Applying change management approaches to engage students

in blended learning

Diana Quinn, Yousef Amer, Anne Lonie, Kim Blackmore,

Lauren Thompson and Malcolm Pettigrove

Tertiary sector

Using blogging and laptop computers to improve writing skills on a vocational training course Nick Marsden and Eileen Piggot-Irvine

Understanding student perceptions and motivation towards academic blogs:

An exploratory study Liping Deng and Allan H. K. Yuen

The iPortfolio: Measuring uptake and effective use of an institutional electronic portfolio in higher education Brian R. von Konsky and Beverley Oliver

Impact of static graphics, animated graphics and mental imagery on a complex

learning task Feng-Qi Lai and Timothy J. Newby

The challenges and opportunities for professional societies in higher

education in Australasia: A PEST analysis Iain Doherty, Caroline Steel and Dominique Parrish

Effects of presentation mode on mobile language learning: A performance

efficiency perspective

I-Jung Chen, Chi-Cheng Chang and Jung-Chuan Yen

\section{Schools sector}

Primary school teachers' use of digital resources with interactive whiteboards:

The Australian context Damian Maher, Renata Phelps, Nikkita Urane and Mal Lee

Using a wiki-based collaborative process writing pedagogy to facilitate

collaborative writing among Chinese primary school students

Xuanxi Li, Samuel Kai Wah Chu, Wing Wah Ki and Matsuko Woo

The Australasian Journal of Educational Technology (AJET) is a refereed research journal published 8 times per year by the Australasian Society for Computers in Learning in Tertiary Education (ascilite). AJET retired its printed version (ISSN 1449-3098) at the end of Volume 23, 2007, and from Volume 24, 2008, the journal is open access, online only (ISSN 1449-5554), and does not have paid subscriptions. 
(C) 2012 Authors retain copyright in their individual articles, whilst copyright in AJET as a compilation is retained by the publisher. Except for authors reproducing their own articles, no part of this journal may be reprinted or reproduced without permission. For further details, and for details on submission of manuscripts and open access to all issues of AJET published since the journal's foundation in 1985, please see http:/ / www.ascilite.org.au/ajet/

For editorial inquiries, contact the Editor (retirement pending), Assoc Prof Catherine McLoughlin, School of Education (ACT), Australian Catholic University, PO Box 256, Dickson ACT 2602, Australia. Email: Catherine.McLoughlin@acu.edu.au, Tel: +61262091100 Fax +61262091185.

For review process, production, website and business matters, contact the Production Editor (retirement pending), Dr Roger Atkinson, 5/ 202 Coode Street, Como WA 6152, Australia. Email: rjatkinson@bigpond.com, Tel: +61 89367 1133. Desktop publishing (PDF versions) and HTML by Roger Atkinson.

AJET is managed by a Committee comprising ASCILITE Executive nominees, the convenors or nominees from previous ascilite Conferences, and AJET's previous editors and current senior editorial staff (to be reconstituted in 2012-13). The current 2012 Management Committee members are:
Dr Caroline Steel, The University of Queensland, ASCILITE President
Dr Iain Doherty, The University of Hong Kong, ASCILITE Executive Professor Geoffrey Crisp, RMIT University, ASCILITE 2003 Convenor
Dr Rob Phillips, Murdoch University, ASCILITE 2004 Convenor
Professor Peter Goodyear, University of Sydney, ASCILITE 2006 Convenor
Dr Dale Holt, Deakin University, ASCILITE 2008 Convenor
Professor Ron Oliver, Edith Cowan University, AJET Editor 1997-2001
Assoc Prof Catherine McLoughlin (Editor - retirement pending), Australian Catholic Uni
Dr Roger Atkinson (Production Editor - retirement pending)

AJET's Editorial Board (see http:/ / www.ascilite.org.au/ajet/about/ editorialboard.html) reflects the journal's commitment to academic excellence in educational technology and related areas of research and professional practice, our vision of an international journal with an Australasian regional emphasis, and our origins as a professional and learned society publication.

\section{Australasian Society for Computers
in Learning in Tertiary Education ascilite http: / / www.ascilite.org.au/}




\section{Editorial 28(1)}

\section{Two Outstanding Paper Awards made at ascilite Hobart 2011}

The ascilite Conference's Outstanding Paper Awards series continues with two papers given this special recognition at ascilite Hobart 2011.

Martin Olmos and Linda Corrin wrote Academic analytics in a medical curriculum: Enabling educational excellence. They describe this emerging new field and illustrate its contribution to the development and implementation of an innovative and integrated curriculum for the Graduate School of Medicine at the University of Wollongong.

Leading change: Applying change management approaches to engage students in blended learning was written by Diana Quinn, Yousef Amer, Anne Lonie, Kim Blackmore, Lauren Thompson and Malcolm Pettigrove. Their work shows change management principles being used to guide a systematic approach to engaging students into the learning culture associated with the Engineering Hubs and Spokes Project conducted jointly by the Australian National University and the University of South Australia.

Researchers and readers interested in exploring trends that may be discerned in the 13 year history of the Outstanding Paper Awards series will find a list of links in the page "Contents table for editorials" (search for 'outstanding') [1].

Roger Atkinson and Catherine McLoughlin AJET Production Editor and AJET Editor (retirements pending)

\section{Endnotes}

1. AJET. Contents table for editorials.

http: / / www.ascilite.org.au/ajet/about/editorials / contents.html

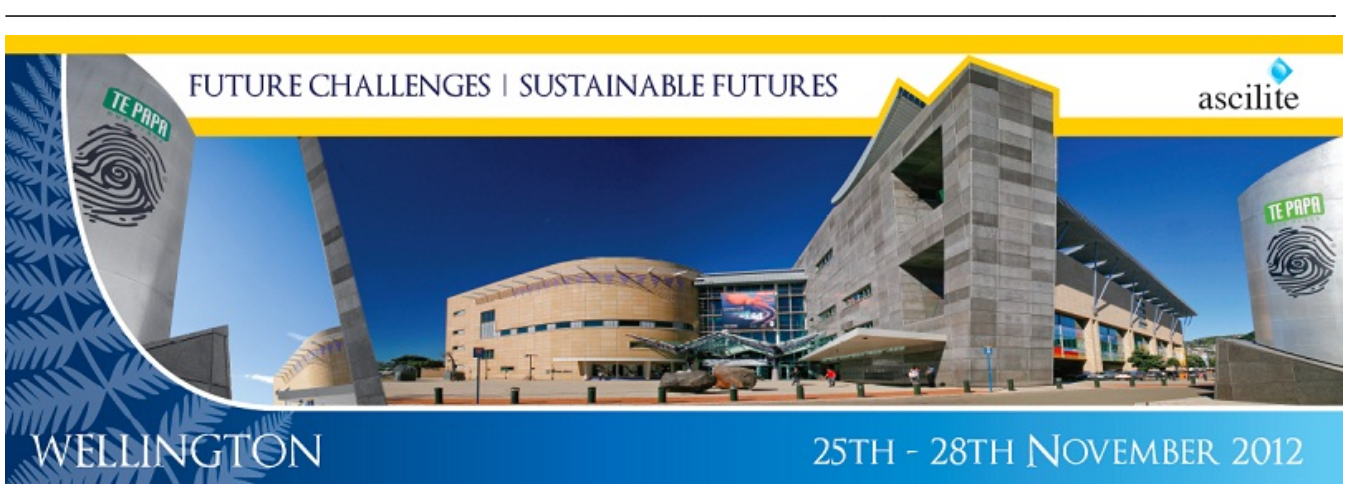

http://www.ascilite.org.au/index.php?p=conference 


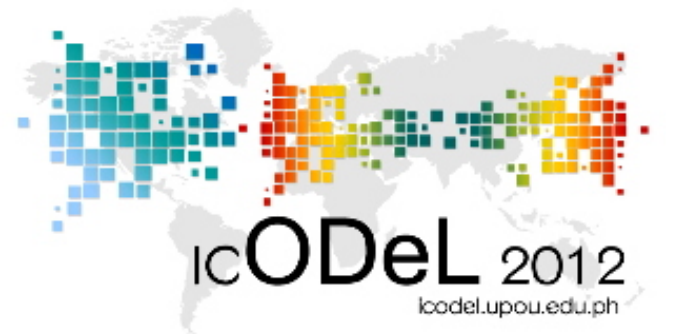

\author{
1st International Conference on \\ Open and Distance e-Learning
}

\title{
Creating Spaces and Possibilities
}

Manila, Philippines, 22-24 February 2012

http://icodel.upou.edu.ph/

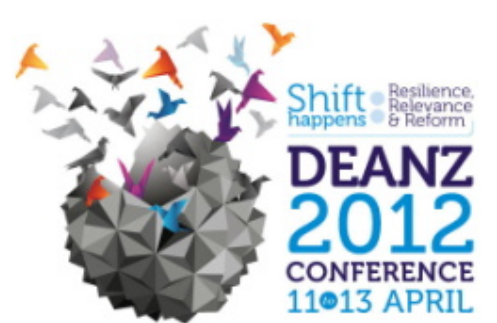

DEANZ 2012 Conference

Shift Happens - Resilience, Relevance and Reform

Distance Education Association of New Zealand

Wellington, 11-13 April 2012

http://www.deanz.org.nz/home/index.php/deanz-conference-2012

\section{HERDSA2012}

Higher Education Research and Development Society of Australasia Inc.

Hobart, 2-5 July 2012. http://conference.herdsa.org.au/2012/
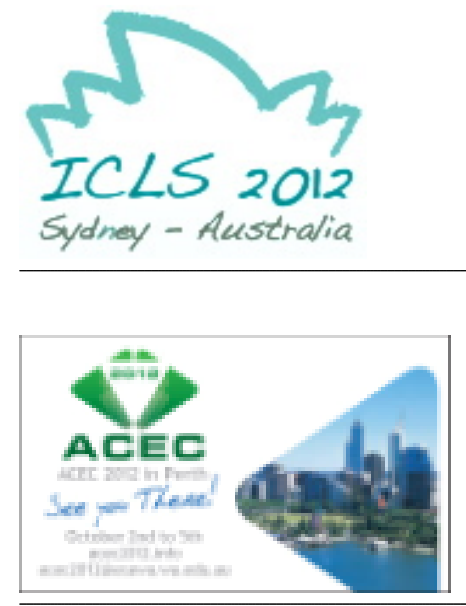

10th International Conference of the Learning Sciences

The Future of Learning

International Society of the Learning Sciences (ISLS)

$$
\text { and }
$$

Centre for Research on Computer Supported Learning and

Cognition (CoCo), University of Sydney, 2-6 July 2012

http://www.isls.org/icls2012/

\section{ACEC 2012}

Australian Council for Computers in Education and the Educational Computing Association of Western Australia

Perth, 2-5 October 2012

http://acec2012.info/ 